\title{
Translation of Non-Equivalent Idioms (using English and Russian examples)
}

\section{Tomáš Jadlovský}

Mesrop Mashtots University of Stepanakert

\begin{abstract}
The author analyses possibilities of translating idioms that do not have corresponding equivalents in the target language. In addition to existing methods described in literature, he proposes translation by means of compensation within a narrow context. The substitute idiom should be chosen from the same phraseosemantic field, and thus, both semantic link to the original text and important stylistic level typical of idioms are preserved in the target text. The theory is demonstrated by examples of translation from English into Russian and vice versa.
\end{abstract}

Key words: translation, idiomatics, non-equivalent idioms, phraseosemantic field, translatological compensation, context, specific stylistic hue of idioms.

\section{Introduction}

The theory and practice of idiom translation is one of the newest areas of linguistic research. It began to be studied in more detail in Slavic studies in the late 1980s, and today a wide range of translating methods are described and summarized in literature (for example Jadlovský 2007:5, 12, 21). The most difficult subject of this branch is represented by idioms that have no equivalents in the target language. They include not only expressions describing unique facts, but also expressions containing a certain connotation of meaning. We shall summarize the accepted translatological methods as well as propose to translate non-equivalent idioms in Slavic idiomatics by means of analogues and compensations, where the substitute idiom from the same phraseosemantic field may be used elsewhere in the target text (Yadlovskiy 2006:84). This study aims 
to employ the mentioned translatological method in languages of various IndoEuropean branches - English and Russian. We shall evaluate the method theoretically and demonstrate it practically using randomly selected texts from the Internet. For this study the phraseosemantic field of Wealth - Poverty which seems to be a universally understood topic developed in language discourse, has been chosen.

\section{Translatological Methods Suggested So Far}

Phraseological translatology aims to implement semantic comparison of phraseological items of different languages as exactly as possible. When translating idioms and other phraseological units, it is necessary to assess correspondence of meaning, semantic composition, determining elements of the idiom and complementary shades of meaning.

This idea applies to idioms more than to any other lexical item, since their very essence lies in the usage in certain types of texts or utterances with respect to a specific stylistic level. A word or free combination of words can be translated without a special attention to the text environment, while some idioms require understanding of close context in order to define the style level, and to find a suitable translation counterpart. In addition to the general linguistic and stylistic nature of the text, while translating idioms the possible individual usage of the idiom 's component in the near vicinity should be taken into account; it may refer to the idiom and thus change the intention of the speaker or writer.

In some extreme cases, even the whole text unit may play a role in translating idioms, if they represent the title of the literary work or the headline of the newspaper article. All contextual possibilities of idioms can never be contained in any dictionary or manual, and it is up to the sense of language and creativity of the translator to assess the adequacy of meaning in both languages.

In linguistic literature, the translation of non-equivalent idioms was approached differently. There is the established point of view that prefers translation by calques (literal translations) (Kravtsova 1977:149). Later, we 
observe inclination towards descriptive or literal translation, not giving preference to any of these methods (Gläser 1998:16), or translation of idioms by a single-word or free connections of words, or by paraphrasing (Buffa 1993:105; Čižmárová 2001:119). All these methods, nevertheless, have their drawbacks. Literal translation is some kind of neologism while the translator should never be an inventor of new meanings or idioms in the target language. Analogical idioms may be difficult to be found and used in specific contexts, and may have unsuitable connotations. Descriptive translation brings about loss of stylistic colouring and text dynamics.

\section{Alternative Possibility of Translating Non-Equivalent Idioms}

All the above-mentioned translation procedures are concerned with the search for an equivalent which would stand in the target text in the same place as in the original one. This is a key moment for us to propose improvement of translatological practice. We believe that there should be an idiom in the target language, and that is why we shall develop the idea of translatological analogy and compensation. This method has already been considered by linguists (Stepanova, Mokienko, Malinski 1995:29) whose short comments however did not go into the details of the question.

Analogues may stand in the same place, but it may happen that we do not find any corresponding expression. As for compensations in translating idioms, we shall not limit our study to their place of occurrence, but also take the context into consideration. We believe that in the absence of a suitable phraseological equivalent, it is possible to use a different idiom, and it could be placed in another part of the target text. This approach is sure to provide a possibility of conserving the stylistic shades of the text that could be lost in case we apply other methods.

Naturally, this way seems to be more appropriate in certain types of longer texts, mainly in educational, popular or journalistic ones, and also in translations of literature, where the translators' work is to deal with semantic shades. To scrutinize this method, we should ask two questions: 
1) To what extent is it possible to place a compensatory idiom in the target text or utterance to make it correspond to the original part? We believe that the width of the text or the length of the utterance can be defined very simply - the lesser the better (probably a single sentence or a few sentences).

2) Which semantic area should the compensatory idiom belong to? Can all contextual possibilities of idiom translation be described? Most probably some guidance could be the application of analogy or compensation within the same phraseosemantic field, which will guaratee at least limited connection of the new idiom in the target language with the original idea.

\section{Phraseosemantic Field as a Source of Substitute Idioms}

Meaning shades and their understanding in idiomatics may be unlimited, and idioms may have different meanings depending on their context. Meanings can also change during some time and the younger generation may understand the same idioms differently than the older one. Likewise, it is improbable to delimit semantic fields so that their boundaries are clear and distinct. Every phraseosemantic field overlaps with other ones. Therefore, we should keep in mind that the search for a suitable idiom in the target language always depends primarily on the context, and in translation practice usage of an idiom from neighbouring fields is not excluded.

We prefer understanding of phraseosemantic fields without word-class constraints. This way, chances of meeting both criteria of sketched compensation - placing idiom as close as possible and, saving connection between meanings of the source idiom and the target one - are more feasible. We shall also try to test synonymic relations of idioms within the phraseosemantic field and use analogues, so that the translator's choices could be wider.

The semantic field of Wealth - Poverty was chosen for our study as sufficiently rich with regard to the historical and social development of both languages. Our English and Russian sources are The Free Dictionary by Farlex (<https://idioms.thefreedictionary.com/>) and The Standard Russian Language Phraseological Dictionary (Fedorov 1995). 
We understand wealth as a high or satisfactory quality of life, consisting of a long-term or permanent surplus or sufficient means of subsistence, with the definitions of financial security, large property or a satisfactory supply of desirable and good food. Similarly, poverty could be defined as a poor quality of life, caused by a long or lasting lack of means of subsistence, manifested by definitions of financial distress, inadequate food supply, inadequate clothing or generally cramped conditions.

In the practical part we shall use texts randomly selected by the computer to demonstrate whether our theoretical assumptions are correct. First, we shall examine synonymous relations between idioms of the same semantic field to test their mutual interchangeability.

\section{King's ransom}

Looking for a gaming laptop that doesn't cost a king's ransom? Well, you're in luck. The Microsoft Store is selling...

(<https://www.pcgamer.com/this-17-inch-gaming- laptopwith-an-amd-ryzen-is-on-sale-for-dollar599/>)

The advertising article from a professional magazine for advanced computer users tells readers that a certain type of computer can be purchased at a reasonable price, certainly not for a large amount of money. For the English idiom, we have found these Russian equivalents - кругленькая копеечка, бешеные деньги, длинный рубль, шальные деньги, шалье деньги, золотой дождь. Out of these terms, бешеные деньги seems to be the most appropriate one; we can propose the following translation: Ищете игровой ноутбук, который не стоит бешеные деньги? Ну, Вам повезло. Магазин Microsoft продает ...

As for other Russian expressions, they could also stand in the same place in the text as fully-fledged equivalents. For instance: Ищете игровой ноутбук, который не стоит шальные деньги / шалые деньги / кругленькую копеечку? Ну, Вам повезло. Магазин Microsoft продает ... In all these options, the 
general meaning of the idiom is faithfully expressed and the stylistic charge is preserved.

\section{Загребать деньги лопатой}

Ходит легенда, что памятник помогает загребать деньги

лопатой, если оставить монету у орудия труда дворника.

(<http://avangard.rosbalt.ru/review/pyat-pamyatnikov-

dvorniku-v-peterburge/>)

The tourist information about St. Petersburg's sculptures of city cleaners mentions the possibility of getting a large amount of money if a tourist leaves a coin at the statue of one of them. There are a lot of English idioms for translation: to make a killing, to make out like a bandit, do some fine coin, coin / be coining money / it, line (one's/somebody's) (own) pocket(s), make / earn a packet, earn / make a mint (of money), make a / one's fortune(s), mint money, to clean up, to make big bucks. It seems to us that the most appropriate translation into English could be: $A$ legend says that the monument helps to make a packet if you leave a coin at the cleaner's tools.

There are also close synonymic relations between idioms, so the translation could be formed in many ways, for example: A legend says that the monument helps to earn a packet / to make a killing / do some fine coin / make a mint (of money) / make a fortune / to make big bucks if you leave a coin at the cleaner's tools. All the idioms mentioned seem to be full equivalent in the specific context as they represent the same meaning as the original Russian idiom and save stylistic hue.

Thus, both examples show that idioms may be synonymous and interchangeable expressions. They have the same relations as words in general.

Second, we will examine translations of idioms without suitable equivalents by analogues.

(To be) born with a silver spoon (in your/his/her mouth) Biden: Trump was 'born with a silver spoon in his mouth' that he's now 'choking on' 
... "This is a guy born with a silver spoon in his mouth that he's choking on because now his foot's in his mouth along with the spoon, "Biden said.

(<https://www.businessinsider.com/joe-biden-donaldtrump-silver-spoon-2016-9>)

The newspaper article describes the political struggle in the United States where the then Democratic Vice President Joe Biden criticized the then Republican President candidate Donald Trump. In his effort to provoke the envy of voters against Trump, Biden emphasized his rich family background. There is no such idiom in Russian, so we shall try to use another expression from the same field within near context. We have to translate this idiom twice, the first time in the headline and the second time in the article proper.

There are two options to treat double translation of the same idiom. The first option is to use the same idiom also twice in the target language, for instance:

Байден: Трамп с роду на всем готовом живёт, и всё же ему не хватает

... «Этому парню, который с роду на всем готовом живёт, всё же не хватает, и хочет больше и больше», - сказал Байден.

We have saved both the meaning and the stylistic hue of the whole article. Nevertheless, we can creatively try to use two different idioms in translation, for example:

Байден: Трамп с роду на всем готовом живёт, и всё же ему не хватает.

... «Этому парню, который с роду живёт на пирокую ногу, всё же не хватает, и хочет больше и больше», сказал Байден. 
It seems to us that the second option in the particular context is even better, at least it shows the translator's ability to avoid automatic usage of the same substitution.

\section{Золотая молодежь}

Не служившая в армии "золотая молодежь" вызвала волну возмущения в Армении

... В высших эшелонах власти Армении обеспокоены волной возмущения, которая была вызвана не служившей в армии золотой молодежью, пишет газета "Грапарак" (Площадь).

(<https://newsarmenia.am/news/society/ne-sluzhivshayav-armii-zolotaya-molodezh-vyzvala-volnu-vozmushcheniyav-armenii/>)

The article describes critical sentiments in Armenian society towards young men from wealthy families who avoided compulsory military service. The idiom also appears twice, in the headline and later in the body of the article. The same idiom can be used twice. For instance:

"Upper crust" not serving in army caused wave of indignation in Armenia

... The highest echelons of Armenian power are concerned about the wave of indignation that was caused by the upper crust boys who did not serve in the army, the Hraparak (Square) newspaper writes.

Here again, both the meaning and the stylistic colouring of the whole article are preserved by the choice of the idiom upper crust from the appropriate semantic field, which complements the denotation of rich young people by the connotation of influential strata of society. If we try to use two different idioms in the English translation, we may reach an even better level of 
translation and use a synonymic idiom from the same field. For example, we may write:

"Upper crust" not serving in army caused wave of indignation in Armenia

... The highest echelons of Armenian power are concerned about the wave of indignation that was caused by the boys of substance who did not serve in army, the Hraparak (Square) newspaper writes.

Third, we will examine translations of non-equivalent idioms which cannot stand in the same place as in the original text, but may be compensated in the target language within the close context.

\section{House poor}

House poor: Canadians who earn the least pay the most for a home.

(<https://globalnews.ca/news/2638885/house-poorcanadians-who-earn-the-least-pay-the-most-for-a-home/>)

The economic comment analyses the housing market situation and draws attention to the relative poverty of under-earning population. The nonequivalent idiom forms part of the article headline and is not mentioned further, therefore the usage of compensation is limited within a short statement. We may translate the article into Russian the following way:

\section{Сложная жизнь: канадцы из-за дорогого жилья едва} сводят концы с концами.

Instead of the original idiom we used free word connection, roughly describing the same meaning. From the semantic point of view, we proceeded correctly, but from the stylistic point of view we deprived the text of its 
phraseological tone and dynamics. We compensated it by using another idiom (едва сводить/свести концы с концами) with a close meaning in the place where the original used common words. We have transferred all the semantic elements even though we have changed the structure of the statement. It may be argued that we could try to use the substitute idiom in the same place. Then we could have, for instance, the following translation:

Затягивай туже ремень: канадцы вынуждены переезжать из-за дорогого жилья.

In our opinion, the first translation has better saved the meaning of the original, because it contains the connotation of difficult life situation. The second translation with the analogue is semantically more distant, it expresses the idea of cutting down expenses. Therefore, the first option is more appropriate.

\title{
Сермяжная душа
}

- Это что там звякает страшным голосом?! Никак тулуп ворот раскрыл?! Сермяжная душа, заткнись сию минуту, селюк!

\author{
(<https://www.neizvestniy- \\ geniy.ru/cat/literature/skazki/1853377.html>)
}

The snippet is from a modern fairy tale in which a vase looking like a simple fur coat and flowers in it speak to each other. The flowers are pretentious and call the ordinary vase by the Russian idiom poor peasants, trying to offend it as simple and thus incomparable with them. There is no similar idiom in English, and we can use for compensation the idiom the bottom of the heap with the meaning of poor and unsuccessful people who have the lowest position in society. Our translation could be as follows:

What is it that sounds, that terrible voice?! It is the bottom of the heap opening the gate?! Fur coat, shut up just now, boor! 
We think we have succeeded to keep all the meanings in the translation the utterance is intended for the fairy fur coat vase, whose name has been changed in the text for an idiom and vice versa. The connotation of peasant remains in the target language and is represented by the simple word - boor. In this case, it does not seem appropriate to place the substitute idiom in the same place in the target text. Although we deal with inanimate objects, the exchange of the Russian idiom with the meaning of individual for the English one with the meaning of group would be confusing. If the substitute idiom is used in the second sentence of the snippet, and the following sentence clearly says that the call is addressed to the fairy fur coat, the reader will not be confused.

Fourth, for the sake of completeness, we shall try to examine the possibility of translating texts without compensation in the close context, but by adding an idiom to the free word translation.

An empty sack cannot stand upright

... Your hypocrisy will be on display.

- And when others see your hypocrisy, you lose credibility and trust.

- Benjamin Franklin, when asked about this subject, quipped that an empty sack cannot stand upright. Without principles, you buckle in the face of adversity.

(<http://exclusive.multibriefs.com/content/theterrible-nature-of-expedient-principles/marketing >)

The article on ethical principles in life and corporate culture brings in the middle of the text an idiomatic quote by Benjamin Franklin. It has no corresponding Russian equivalent. If the paragraph that mentions Franklin's quote is relatively short, and idiomatic dynamics is connected just with the quote, it seems inappropriate to use a substitute idiom in another paragraph. Neither can we use another Russian analogue in the same place, because we would substantially change the quote of the famous person. In this situation, when the whole text is long, the option to translate the proverb by the free 
word connection in Russian, reflecting its meaning, seems to be the best. The lost stylistic shades can be compensated by an idiom standing as supplement. Our translation might look like this:

... Ваше лицемерие будет очевидным.

- A когда другие увидят ваше лицемерие, вы потеряете репутацию и доверие.

- Бенджамин Франклин, когда его спросили об этой теме, пошутил, что недовольный бедняк не может защищать принципы, потому что он в первую очередь сосредоточен на своей более важной проблеме - что в его карманах ветер гуляет. Без принципов вы можете легко попасть в беду.

Although we have abandoned accuracy in terms of the length of the text and set of meanings, in our opinion it is acceptable to save the specific stylistic charge by using another idiom standing close to the original place. Nevertheless, this technique is appropriate only for certain types of texts, it would not fit where the same or similar number of words must be used (poetry, titles, headlines) or in simultaneous oral interpretation where the interpreter could lose valuable time and continuity of meaning.

\section{Лаптем щи хлебать}

Лаптем щи хлебать: как россияне давятся родным

Россия сокращает импорт автомобилей, одежды, обуви, продовольствия. Всего в мае за рубежом было приобретено товаров на \$20 млрд, это на 3\% меньше, чем в апреле. А по сравнению с прошлым годом...

(<https:/finance.rambler.ru/money/42401044-laptem-schihlebat-kak-rossiyane-davyatsya-rodnym/>) 
The article on economic development in Russia has a brief headline with a non-equivalent idiom. It does not appear more below, the whole article is entirely a technical text on economics and its author used the idiom only as a lure in the headline. No English idiom can be used in the same place as an analogue. The headline is relatively short and we cannot proceed as in the previous example. That is why we have to choose whether to leave phraseological stylistic dynamics or to place in the target text any other idiom as close to the original idiom as possible. In our opinion, the translator should always try to maintain the stylistic charge of the original text, so we tend to use the second option, which could be realized in the following way:

\section{Russia is poorer and lags behind in figures}

Russia tightens her belt; she is reducing the import of cars, clothes, shoes, food. In total, goods worth $\$ 20$ billion were purchased abroad in May, which is 3\% less than in April. And compared to last year...

In the headline we strictly follow the transfer of meaning. The use of the substitute idiom was not possible there as it would undesirably distort the main idea of the article. We placed the substitute idiom at the beginning of the first article clause, where it is clear that the economic and life-style modesty described by the idiom refers to the import of goods, not to the overall economic situation of Russia. The stylistic dynamics is thus missed only in the headline but saved in the article as a whole.

\section{Conclusion}

In addition to the existing translation procedures, we have proposed a new method of translation of non-equivalent idioms, which retains both meaning and stylistic value in certain types of texts. The semantic fields of idioms may represent a source of substitute expressions for translators. We have discovered that synonymous relationships between idioms work the same way as generally established in lexicology. Idioms of similar meaning may be interchanged and 
used in translating practice. Non-equivalent idioms may be translated by means of analogues in the same place of a text or using compensations within the close context.

The proposed method has been proved to be applicable. We have reviewed it both for long texts, and for short text sections such as newspaper headlines. If translation by idiom is not possible in the original location, the translator should try to compensate it in another place as close as possible.

\section{References:}

1. Buffa, F. (1993) O pol'skej a slovenskej frazeológii. Bratislava: Veda.

2. Čižmárová, M. (2001) Ekvivalenčné typy frazém $v$ ukrajinčine a slovenčine. // Slavica Slovaca, 36. Bratislava: SÚJS SAV.

3. (1995) Frazeologicheskiy slovar' russkogo literaturnogo yazyka. / Ed. by A.I. Fedorov. Novosibirsk.

4. Gläser, R. (1998) The Translation Aspect of Phraseological Units in English and German. // Topics in Phraseology, Theory and Practise. Vol. 1, Katowice.

5. Jadlovský, T. (2007) Frazeosémantické pole "bohatství - chudoba" v českoruském srovnávacím plánu. / Ph.D. Dissertation. Available at: $<$ https://is.muni.cz/th/m8t1b/> [Accessed July 2019].

6. Kravtsova, S.I. (1977) Sposoby peredachi frazeologicheskikh yedinits russkogo yazyka na ukrainskiy (na materiale perevoda dramy L.N. Tolstogo "Vlast't'my»). // Problemy russkoy frazeologii. Tula.

7. Stepanova, L.; Mokienko, V.; Malinski, T. (1995) Russkaya frazeologiya dlya chekhov. Olomouc.

8. (2019) The Free Dictionary by Farlex. Available at: <https://idioms.thefreedictionary.com/> [Accessed July 2019].

9. Yadlovskiy, T. (2006) Perevod frazeologizmov v ramkakh semanticheskogo polya (na materiale russkogo i cheshskogo yazykov). // Vesnik BDU Seriya 4 - Filalohiya - Zhurnalistyka - Pedahohika, № 1. Minsk: BDU. 


\section{Sources of Data:}

1. Laptem shchi khlebat: Kak rossiyane davyatsya rodnym. Rambler/Finansy. Gazeta.ru (26 June 2019) Available at: <https://finance.rambler.ru/money/42401044-laptem-schi-hlebat-kak-rossiyane-davyatsya-rodnym/> [Accessed March 2020].

2. Lilly, P. (2019) This 17-inch gaming laptop with an AMD Ryzen is on sale for \$599. PC Gamer. Available at: <https://www.pcgamer.com/this-17inch-gaming-laptop-with-an-amd-ryzen-is-on-sale-for-dollar599/> [Accessed March 2020].

3. Mehler Paperny, A. (2016) House poor: Canadians who earn the least pay the most for a home. Global News. Available at: <https:/globalnews.ca/news/2638885/house-poor-canadians-who-earn-the-least-pay-the-mostfor-a-home/> [Accessed March 2020].

4. Ne sluzhivshaya v armii zolotaya molodezh vyzvala volnu vozmushcheniya v Armenii. AMI Novosti Armenia (4 July 2017) Available at: $<$ https://newsarmenia.am/news/society/ne-sluzhivshaya-v-armii-zolotayamolodezh-vyzvala-volnu-vozmushcheniya-v-armenii/> [Accessed March 2020].

5. Rose, A. (2019) The terrible nature of expedient principles. Multi Briefs: Exclusive. Available at: <http://exclusive.multibriefs.com/content/the-terrible-nature-of-expedient-principles/marketing> [Accessed March 2020].

6. Shishkova, K. (2016) Pyat' pamyatnikov dvorniku v Peterburge. Peterburgskiy avangard. Available at: <http://avangard.rosbalt.ru/review/pyatpamyatnikov-dvorniku-v-peterburge/> [Accessed March 2020].

7. Shust, S. (2017) Bomond v litrovoy banke. Neizvestniy geniy. Available at: <https://www.neizvestniy-geniy.ru/cat/literature/skazki/1853377.html> [Accessed March 2020].

8. Tani, M. (2016) Biden: Trump was 'born with a silver spoon in his mouth' that he's now 'choking on'. Business Insider. Available at: <https://www.businessinsider.com/joe-biden-donald-trump-silver-spoon2016-9> [Accessed March 2020]. 


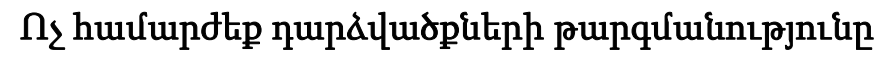

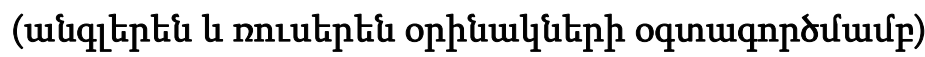

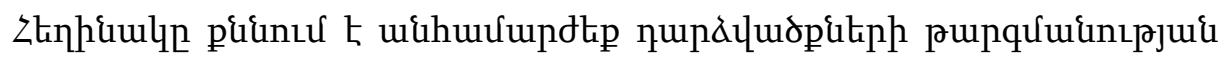

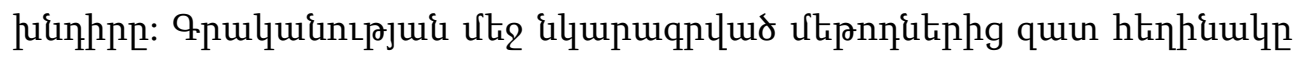

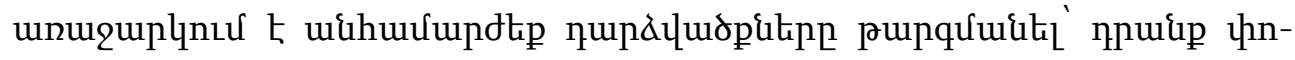

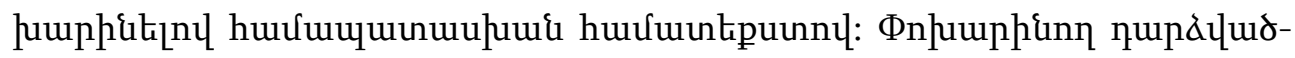

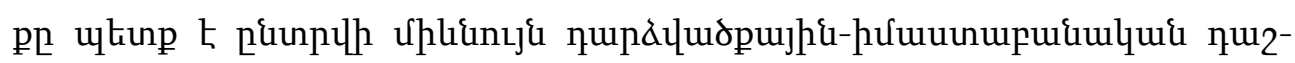

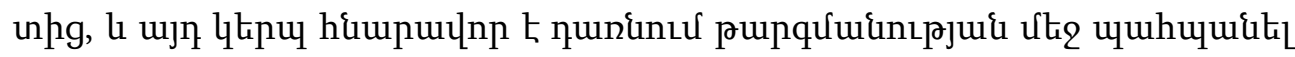

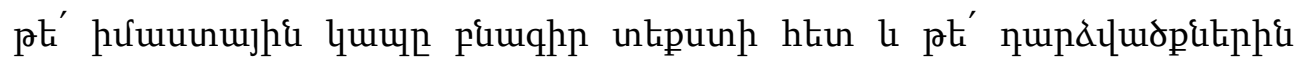

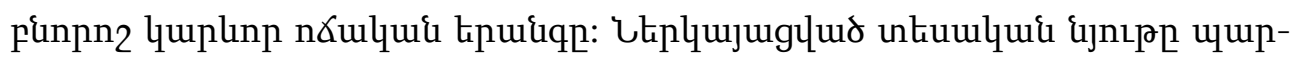

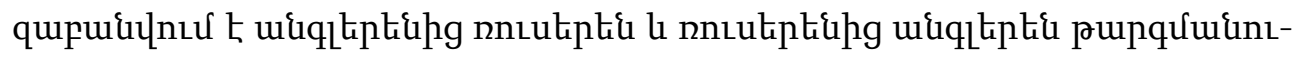
pjnıkitiph huuunulquí ophiaulqutennц:

Received by the Editorial Board 18.05.2020

Recommended for publication by the reviewers 20.07.2020

Accepted for print 05.10.2020 